\title{
Agricultural groundwater management in the Upper Bhima Basin, India: current status and future scenarios
}

\author{
L. Surinaidu ${ }^{1}$, C. G. D. Bacon ${ }^{2,3}$, and P. Pavelic ${ }^{1}$ \\ ${ }^{1}$ International Water Management Institute, Hyderabad, India \\ ${ }^{2}$ Department of Earth Sciences, University of Bristol, Bristol BS8 1RJ, UK \\ ${ }^{3}$ Golder Associates (UK) Ltd., Bourne End, SL8 5AS, UK
}

Correspondence to: L. Surinaidu (1.surinaidu@ @ cgiar.org)

Received: 4 September 2012 - Published in Hydrol. Earth Syst. Sci. Discuss.: 20 September 2012

Revised: 26 December 2012 - Accepted: 12 January 2013 - Published: 6 February 2013

\begin{abstract}
The basaltic aquifers of the Upper Bhima River basin in southern India are heavily utilized for small-scale agriculture but face increasing demand-related pressures along with uncertainty associated with climate change impacts. To evaluate likely groundwater resource impacts over the coming decades, a regional groundwater flow model for the basin was developed. Model predictions associated with different climate change and abstraction scenarios indicate that the continuation of current rates of abstraction would lead to significant groundwater overdraft, with groundwater elevations predicted to fall by $-6 \mathrm{~m}$ over the next three decades. Groundwater elevations can however be stabilized, but would require $20-30 \%$ of the mean surface water discharge from the basin to be recharged to groundwater, along with reductions in pumping (5-10\%) brought about by improved water efficiency practices and/or shifts towards lowerwater use crops. Modest reductions in pumping alone cannot stabilize groundwater levels; targeted conjunctive use and improved water use efficiency are also needed.
\end{abstract}

\section{Introduction}

Hardrock crystalline aquifers cover approximately two-thirds of India, providing a vital yet finite groundwater resource that greatly supports India's food and livelihood security (World Bank, 2010). The contribution from groundwater to India's GDP has been estimated at about 9\% (Mall et al., 2006), with the demand from the non-agricultural sectors rising (Shah, 2009a). Since 1960, the area irrigated with groundwater has increased 5-fold (Garduño and Foster, 2010) and groundwater is presently the source for over $60 \%$ of the irrigated areas. This growth has been supported by increasing availability in supply of drilling equipment, mechanical pumps and rubber pipes, combined with conducive government policies (Foster et al., 2007; Shah, 2009a). With the steadily rising food demand brought about by population pressures, there is concern that in many regions of India groundwater development may exceed safe exploitation levels. As well as this consideration, there are uncertainties associated with future climate change and so sustainable management of water resources becomes very challenging whilst achieving development targets.

The impacts of climate change are expected to be most severe across low latitudes and the developing world in particular, including India, because of the lower capacity to adapt (Gosain et al., 2006). Climate change will affect river discharges directly through changes in the major long-term climate variables (Scibek et al., 2007; Jyrkama and Sykes, 2007). The impacts of climate change on groundwater has been investigated by many researchers (Loáiciga et al., 2000; Varanou et al., 2002; Brouyère et al., 2004; Allen et al., 2004; Krysanova et al., 2005; Scibek and Allen, 2006; Andersen et al., 2006; Jyrkama and Sykes, 2007) who have largely reported significant impact from climate change on groundwater recharge and its availability in the future. Aquifer systems have greater buffering capacity against droughts and climate fluctuations compared to surface water sources (Dragoni and Sukhija, 2008; Shah, 2009b). However, hard rock aquifers, such as those of India are vulnerable as these have low groundwater storage and yields tend to decrease rapidly with depth as the weathering-related permeability is reduced, 
thereby making the deepening of wells in response to falling water tables less viable. However the fracturing and jointing present below the upper weathered zone supports additional extraction of groundwater from further depths in some parts.

The focus for this study is the Upper Bhima Basin, an area of $46000 \mathrm{~km}^{2}$ in India (Fig. 1) where the groundwater provided by the basaltic aquifers helps to sustain the lives of 15 million people; 9 million of which are in rural areas (2001 Census figures). The groundwater resources of the basin are extensively utilized, with around $70 \%$ of the average annual recharge withdrawn for consumptive uses, and many subareas having groundwater development greater than safe levels for exploitation according to Government of India protocols (Chaterjee and Purohit, 2009). Shallow dug wells are prone to drying out in areas where the weathered profile is thin and underlain by hard compact basalt that tends to limit recharge during the wet season (Kharif). Average residence time of the shallow, accessible groundwater is less than four years and therefore two or more consecutive years of drought can seriously threaten the livelihoods of smallholder farming communities (Pavelic et al., 2012). Despite this, the subbasin is a major surface water-exporter, which also creates opportunities for enhancing groundwater recharge and for effective conjunctive use of water resources (Venot, 2009; Garg et al., 2011a). Further, it should be noted that almost all studies in the area focus on recharge estimation, watershed development, resource exploration and its availability (Doleankar, 1980; Kulkarni and Doleankar, 1995; Kulkarni et al., 2005; Immerzeel et al., 2006; Limaye, 2010; Garg et al., 2011a; Pavelic et al., 2012). Gartley et al. (2009) investigated security of supply associated with possible future changes in water demand. None of the studies have focused on future availability of groundwater resources with changes in demand and supply associated with climate change and watershed development.

In the present study we addressed unresolved issues concerning future sustainability of the groundwater resources in response to the effects of climate and demand-related pressures. The objective of this study is to address these issues through the use of numerical groundwater modelling techniques to simulate groundwater flows and availability within the Upper Bhima Basin under a range of future scenarios in order to identify viable policy options.

\section{Hydrology, agriculture and climate}

The Krishna River basin is the fifth largest river system in India, with a discharge of $69.8 \mathrm{~km}^{3} \mathrm{yr}^{-1}$, draining an area of nearly $260000 \mathrm{~km}^{2}$. The Bhima River is one of two major tributaries of the Krishna and the Upper Bhima sub-Basin, situated almost entirely within the Indian state of Maharashtra, is one of twelve sub-basins of the Krishna River basin (Biggs et al., 2007). The headwaters of the three major rivers in the Upper Bhima sub-Basin (the Sina, Bhima, and Nira),

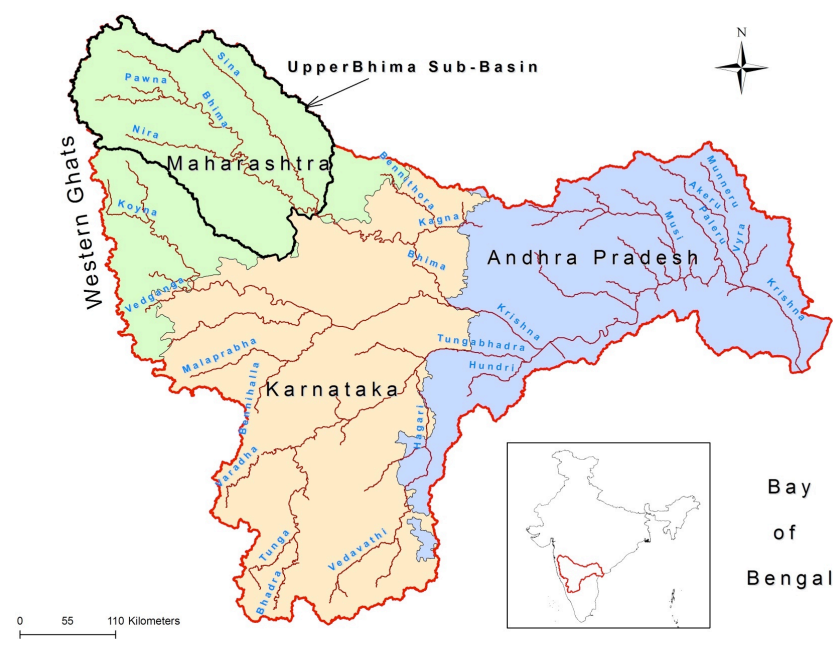

Fig. 1. Location of the Upper Bhima sub-Basin within the Krishna River basin, southwestern India.

originate in the dense forests on the eastern side of the Western Ghats range. These rivers flow to the southeast, over the plains of the Deccan Plateau, a fertile agricultural area with densely populated riverbanks. Natural river flows are ephemeral, having been steadily influenced by many irrigation canal structures and dams, with the Ujjani dam as the largest (Biggs et al., 2007).

Agriculture is the largest consumer of water in the Bhima Basin, with about $70 \%$ of total land area under agriculture. The soils are predominantly vertisols, typical for the geology and climate. These soils have a high content of the expansive clay montmorillonite, which makes them almost impermeable when saturated, and therefore suitable for rice production. The natural vegetation is grassland, savanna or grassy woodland. The major crops grown in this basin are sugarcane, sorghum, wheat, corn, millet, groundnut, fodder grass and a variety of other horticultural crops. Irrigated crops such as sugarcane and sorghum account for $25 \%$ of the total geographical area in the Kharif and Rabi seasons (Garg et al., 2011a).

The climate of the Upper Bhima is highly variable, both spatially and temporally. Most of the rainfall falls on the eastern side of the Western Ghats $\left(>4000 \mathrm{~mm} \mathrm{yr}^{-1}\right)$, whilst the plains of the Deccan Plateau receive $<500 \mathrm{~mm} \mathrm{yr}^{-1}$. The average rainfall over the basin is $872 \mathrm{~mm} \mathrm{yr}^{-1}$ (Pavelic et al., 2012). Of the annual rainfall, $80-90 \%$ falls intermittently during the monsoon period from June to October.

\section{Hydrogeology}

The Upper Bhima sub-Basin is situated in the Deccan Plateau, a large igneous province composed of Deccan Trap basalts. These erupted at the end of the Cretaceous era and cover an area of approximately $500000 \mathrm{~km}^{2}$ (Deolankar, 
1980). The Deccan Trap basalt is composed of vesicular amygdaloidal basalt and compact basalt layered horizons. A red tuffaceous layer, sometimes referred to as red bole, often caps the vesicular amygdaloidal basalt and represents the glassy top of a lava flow. Each lava flow ranges in thickness from only a few meters to approximately $100 \mathrm{~m}$. The maximum thickness of all flows is approximately $1.5 \mathrm{~km}$ (Saha and Agrawal, 2006).

Groundwater is present under shallow unconfined or semiconfined conditions in the mantle of local alluvium, laterite and weathered upper portion of the Deccan Trap basalts. The basalts possess little or no primary porosity; the groundwater resource potential is controlled by the degree of weathering, geomorphological and geological features, such as the size and distribution of vesicles, and the frequency and interconnection of joints and fractures (Kulkarni et al., 2000). The aggregate porosity for fractured-jointed basalt ranges up to $15 \%$ (Deolankar, 1980). The horizontal layering of the basalt lava flows and the high clay content of the red bole horizons impart a degree of transverse isotropy that restricts vertical flow of groundwater. The basalt aquifers are also anisotropic, due to fractures and dykes, which channel, or block the flow of groundwater, dividing the system into smaller hydrogeological units. The maximum depth of useful quantities of groundwater is usually limited to about $100 \mathrm{~m}$ (Limaye, 2010). Water level trends from observation wells and piezometers from the study area reveal that shortterm rainfall only improves soil moisture and serves farmers, but only adequate rainfall over long duration can replenish groundwater.

\section{Groundwater use}

Groundwater in the basalts is generally fresh and potable, although some areas have been polluted due to the use of chemical fertilizers, pesticides and unregulated discharge of industrial and municipal waste (Limaye, 2010). Groundwater is generally extracted from large diameter dug wells or dug-cum bore wells screened in the weathered portion of the basalt. These wells are generally 3 to $8 \mathrm{~m}$ wide and 8 to $15 \mathrm{~m}$ deep. Typical yields are in the range of $1-100 \mathrm{~m}^{3} \mathrm{day}^{-1}$, supporting an average land holding per farming family of around 2 ha (Limaye, 2010). With depth, the basalt becomes more compacted, unaltered, and the widths of the fracture decrease and well yields reduce significantly. Therefore, deepening wells to chase falling water levels is often ineffectual (Foster et al., 2007). Groundwater elevation responds quickly to recharge, due to the low storage characteristics of the basalts. The groundwater elevations generally vary between 2 to $10 \mathrm{~m}$ below ground level (b.g.l.) depending on the time of year, and the total depth of wells varies between 3.8 to $36.1 \mathrm{~m}$ with a mean depth of $10.8 \mathrm{~m}$.

Data from 135 pumping tests from dug and bore wells across the Upper Bhima Basin and adjacent areas supplied by the Groundwater Surveys and Development Agency (GSDA) were interpreted using the Jacob equation (with typical assumptions). The estimated storage coefficient using Jacob's formula ranges from 0.01 to 0.08 . For unconfined aquifers the storage coefficient virtually equals to specific yield $\left(S_{\mathrm{y}}\right)$, hence storage coefficient was taken as the specific yield in the basin. Specific yield $\left(S_{\mathrm{y}}\right)$ 5th percentile, median, and 95th percentile values were calculated as $0.01,0.03$ and 0.08 , respectively. Corresponding transmissivity values are $5 \mathrm{~m}^{2}$ day $^{-1}, 45 \mathrm{~m}^{2} \mathrm{day}^{-1}$ and $200 \mathrm{~m}^{2} \mathrm{day}^{-1}$. $S_{\mathrm{y}}$ values range between 0.01 and 0.025 for basaltic rocks (Chatterjee and Purohit, 2009), and the GEC (Groundwater Resource Estimation Committee) state $S_{\mathrm{y}}=0.02$ for weathered or vesicular, jointed basaltic terrains (Government of India, 1997). The relatively higher $S_{\mathrm{y}}$ value of 0.08 compared to 0.025 can be attributed to the GSDA data being predominantly derived from testing of shallow dug wells that bias the uppermost (weathered) part of the aquifer, which will also have greater permeability than deeper portions. It also represents the most active depth at which the replenishable water (every monsoon) exists and is discharged throughout the single hydrological cycle. The interconnection between the vesicles and the degree of deposition of zeolites in the vesicles determines the aquifer parameters. Cooling joints and sheet joints within thick lobes are the other loci where water is stored (Kulkarni and Deolankar, 1995). Transmissivity values for weathered basalts, vesicular basalts and fracture-jointed basalts of the Deccan Traps range from 90 to $200 \mathrm{~m}^{2} \mathrm{day}^{-1}, 50$ to $100 \mathrm{~m}^{2}$ day $^{-1}$ and 20 to $40 \mathrm{~m}^{2} \mathrm{day}^{-1}$, respectively (Deolankar, 1980).

\subsection{Model conceptualization}

At a regional scale, the hydrogeology of the Upper Bhima River basin can be divided by depth into three sub-units: a weathered upper zone with sub-horizontal sheet joints, a middle zone comprising compact basalt with decreased jointing, and a lower zone associated with sub-horizontal and vertical joints. Figure 2 presents a conceptual model of the hydrogeological system extending longitudinally across the study area based on previous studies carried out for groundwater exploration and hydrogeological mapping in the area (Deolankar, 1980; Kulakarni, 1987; Kulakarni et al., 2005; Phadnis et al., 2005; Maurya and Vittal, 2011). This model suggests that the weathered and jointed portion is limited to the upper $50 \mathrm{~m}$ below ground surface, followed by compacted basaltic flows whilst the lower part is associated with vertical joints and occasional horizontal discontinued joints. The upper $50 \mathrm{~m}$ the aquifer is the most transmissive layer. The vertical joints act as conduits to recharge the deeper aquifers (Fig. 2). Higher specific yields arise in weathered and dissected sheet joint units, whereas the massive basalt unit has a lower specific yield (Saha and Agrawal, 2006). Initially the model was set-up as a single layer aquifer with a $20 \mathrm{~m}$ thickness, but at several locations in upstream 


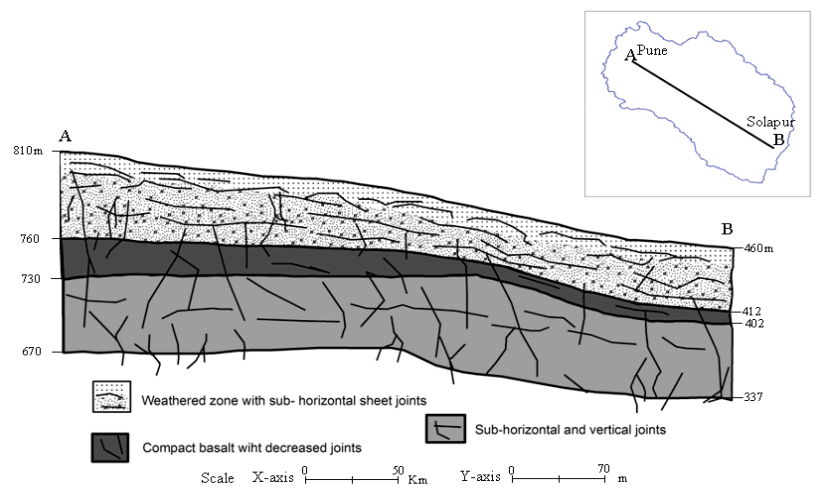

Fig. 2. Generalized geological cross section of Upper Bhima Basin (modified after Phadnis et al., 2005; Kulkarni et al., 2005; Saha and Agrawal, 2006; Maurya and Vittal, 2011).

and downstream areas cells dried out during the simulation. Hence the model thickness was increased to $50 \mathrm{~m}$, which offers the best compromise between reality and the effective functioning of the model. Depth variations in specific yield within the upper $50 \mathrm{~m}$ portion modelled were not applied as the model was intended to represent larger regional scale processes rather than local level variability. It was considered that the groundwater resource availability in the upper layer far exceeds that below, and is the most significant groundwater resource utilised in this region. The hydrogeologic properties of the bottom portion below $50 \mathrm{~m}$ are more heterogeneous in nature, with much less data available, and were not included in the model. Therefore, the model aims to simulate groundwater flow for the upper active weathered zone associated with sheet joints, with a uniform thickness of $50 \mathrm{~m}$ and uniform $S_{\mathrm{y}}$ within the range specified in the above section over the entire modelled domain (Fig. 2).

A quasi-3D, finite-difference groundwater flow model was constructed using Visual MODFLOW (Waterloo Hydrogeologic, 2002). This finite-difference, block-centered, 3D modelling package can simulate transient groundwater flows for different hydrogeological systems (McDonald and Harbaugh, 1988). The conceptual model of the Upper Bhima hydrogeological system was based on hydrological and subsurface geological data available in the literature. The sub-basin was modelled as an equivalent porous medium (EPM). The EPM method requires the cell-size of the groundwater model be sufficiently large, so that flow within an irregular medium behaves as if in a regular, porous medium when modelled on a sufficiently large scale (Singhal and Gupta, 1999). This method and the application of uniform hydrogeological properties in the model are considered justified for this region because, at a regional scale, the hydrogeological properties of the basin are broadly consistent.

The grid cells were uniformly fixed at $1 \mathrm{~km} \times 1 \mathrm{~km}$. The ground surface elevations were taken from Shuttle Radar
Topography Mission (SRTM) data (http://www2.jpl.nasa. gov/srtm/). The original data has a resolution of $90 \mathrm{~m}$, which was downscaled to $1 \mathrm{~km}$ resolution to match the grid cell size in the model.

\subsection{Model and boundary conditions}

Hydrogeological input parameters were selected from the ranges stated above for calibration purposes. The low hydraulic conductivities in this region, range from 0.01 to $1.5 \mathrm{~m} \mathrm{day}^{-1}$ (Limaye, 2010). The vertical hydraulic conductivity $\left(K_{z}\right)$ was set at $10 \%$ of the horizontal hydraulic conductivity $\left(K_{x y}\right)$ to reflect the layered composition of the basalt flows. A uniform hydraulic conductivity coefficient was applied for the region, as justified by modelling as an EPM. The values selected to calibrate the model were taken from the range 0.05 to $0.86 \mathrm{~m}$ day $^{-1}$.

The upland regions occupy less than $30 \%$ of the present study area and are associated with limited permeability and storage. Whilst these areas were not specifically described in the model, they are still taken into account through relationships developed between rainfall and groundwater levels that were developed throughout the basin as a whole (described below). The surface watercourses in the sub-basin have complex discharge patterns, and have undergone many anthropogenic alterations at a range of scales (Biggs et al., 2007). Data for the characteristics of these courses (such as river widths, stage heights, stream bed thickness and conductivity) were unavailable and therefore it was not possible to directly include surface water features in the model. Hence, net recharge from all hydrological components and groundwater discharge in the catchment was estimated based on empirical equations derived between groundwater levels and rainfall by Pavelic et al. (2012). Modelled volumes of groundwater pumping was simulated as negative recharge in the model. A constant head boundary was placed along the southeast edge of the model domain, $5.5 \mathrm{~m}$ below the ground level, coinciding with mean groundwater elevation along this boundary (Fig. 3). This allows it to act as an outflow for groundwater discharge which is expected at this lowest part of the basin.

\section{Recharge inputs}

Across the Upper Bhima Basin, recharge rates are spatially variable and affected by rainfall patterns, local scale topography, and soil thickness. Demand for water differs across the basin depending on crop type and other factors; and water supply may be either from rainfall, ponds, canals or groundwater. The model does not account for local-scale disparities in supply and demand. Modelling using spatially varied recharge, based on the limited rainfall distribution IMD data (India Meteorological Department), was attempted but not found to improve the model results. This further supports the approach to model the basin uniformly, as the scale is 


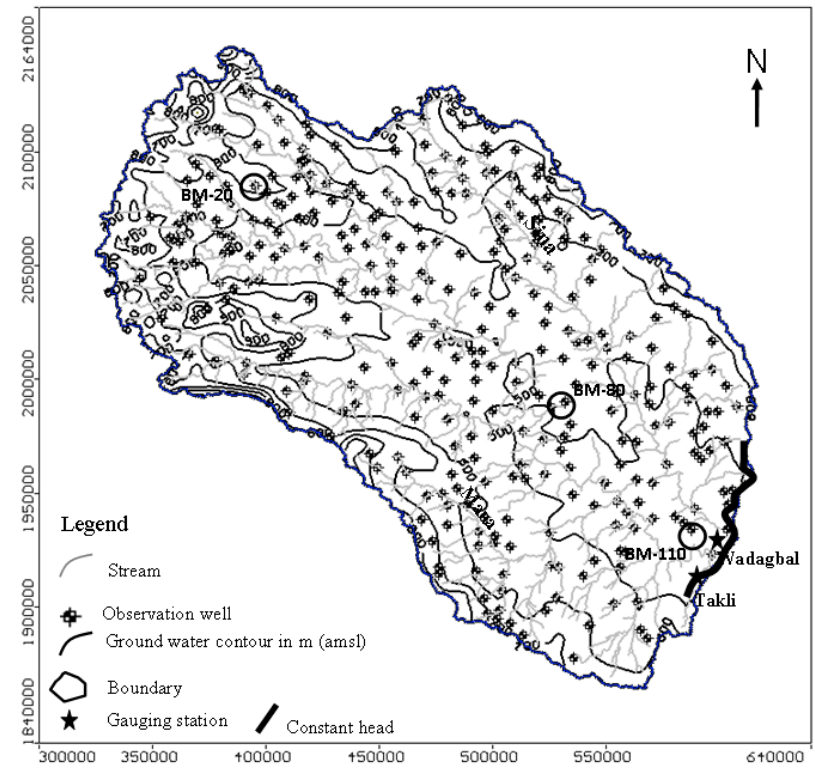

Fig. 3. Location of observation wells and groundwater contours in metres (a.m.s.l.) - June 2008.

large enough to average out local-scale variations. Therefore, spatially uniform (basin aggregated) and temporally variable average recharge (and discharge) was applied across the basin. Most of the rainfall occurs during the monsoon months only (June to September). Therefore, all rainfall (and thus recharge - see below) was modelled to occur in the monsoon (Kharif) season, and all pumping during the non-monsoon (Rabi) season (October to May).

Input data for annual recharge and discharge water budgets were taken from the Groundwater Surveys and Development Agency (GSDA). The GSDA has identified 195 groundwater resource watersheds within the Maharashtra portion of the Upper Bhima sub-Basin (the Karnataka portion constitutes only $1.6 \%$ of the Upper Bhima area and was ignored in this study). The GSDA reports average annual water balances for these watersheds, which are calculated by adjusting watershed water volumes by assigning weights to each of the watershed areas. These data from the two most recent assessment periods that are most related to the calibration period (2000 to 2004, and 2004 to 2008) were averaged to provide estimated annual groundwater availability (net recharge) of $100 \mathrm{~mm}$ and an annual gross draft (extraction or pumping) of $65 \mathrm{~mm}$. Further, it was assumed that in the wetter years there will be more groundwater recharge and that the demand for groundwater abstraction will be less (whilst the opposite applies for drier years than average). The recharge and pumping annual means were therefore weighted in linear proportions (positively and inversely, respectively) with annual precipitation data (IMD rainfall data).

The following relationships were derived, based on the rainfall-weighted annual recharge and pumping budgets versus annual rainfall data (Pavelic et al., 2012).
Recharge $[\mathrm{mm}]=0.1133 \times$ rainfall $[\mathrm{mm}]-5 \mathrm{E}-13$

Pumping (modelled as negative recharge) $[\mathrm{mm}]=$

$$
-0.0737 \times \text { rainfall }[\mathrm{mm}]+130
$$

This method derives an average groundwater recharge coefficient of approximately $11 \%$ of rainfall. This coefficient is in agreement with other reported values for basaltic terrain such as in the Groundwater Resource Estimation Committee methodology (commonly known as GEC-1997) (Chaterjee and Purohit, 2009) and within the $3 \%$ and $13 \%$ range reported by Limaye (2010).

\section{Model calibration}

The model was calibrated using data from 313 observation wells (Fig. 3) using the root mean square (RMS) and normalized root mean square (NRMS) error as the goodnessof-fit measure. The model calibration was achieved through trial and error method by adjusting two key parameters viz., specific yield and hydraulic conductivity. It was found that the model was more sensitive to hydraulic conductivity. The resultant errors and sensitivity to the hydraulic conductivity $\left(K_{x y}\right)$ and specific yield $\left(S_{\mathrm{y}}\right)$ were evaluated for the calibration period with different $K_{x y}$ inputs, ranging from $0.05 \mathrm{~m} \mathrm{day}^{-1}$ to $0.86 \mathrm{~m} \mathrm{day}^{-1}$ and specific yield inputs from 0.01 to 0.03 (Table 1 ). Initially the model was run under steady-state conditions and simulated heads were assessed against observed heads. The observed versus computed heads are shown in Fig. 4.

Due to the broad averaging of input parameters, the quality of calibration does vary from one observation well to another, as indicated by the hydrographs for three representative observation wells (Fig. 5). However, the calibrated model was considered to be sufficiently robust to enable predictive modelling of major trends within the basin, but not necessarily of high accuracy at the local scale. The model results show a good calibration using $K_{x y}=0.86 \mathrm{~m} \mathrm{day}^{-1}$ and $S_{\mathrm{y}}=0.03$, with a root mean square error of $4.5 \mathrm{~m}$, normalized error $1.02 \%$ and exhibiting reasonable agreement between simulated and observed head data over the $11 \mathrm{yr}$ period. Therefore, these aquifer properties were selected in the subsequent prediction stage (described below). For each of the forecast scenarios described in the next section, modelling was performed under transient conditions with 27 stress periods, assuming steady-state conditions as the initial conditions.

\section{$7 \quad$ Future rainfall projections}

Future climate scenarios were modelled from the end of the calibration period record (2007) until 2040 (thirty years is the classic forecast period, as defined by the World Meteorological Organisation; Government of India, 2008). Global 
Table 1. Quantitative results for the various calibration runs.

\begin{tabular}{llrrr}
\hline \multirow{2}{*}{$\begin{array}{l}K_{x y} \\
\left(\mathrm{~m} \mathrm{day}^{-1}\right)\end{array}$} & $\begin{array}{l}\text { Calibration } \\
\text { measure }\end{array}$ & \multicolumn{3}{c}{ Percent error } \\
\cline { 3 - 5 } 0.05 & RMS & 4.436 & 4.506 & 4.53 \\
& NRMS & 0.918 & 1.014 & 1.019 \\
0.08 & RMS & 4.436 & 4.506 & 4.531 \\
& NRMS & 0.92 & 1.021 & 1.023 \\
0.1 & RMS & 4.436 & 4.506 & 4.531 \\
& NRMS & 0.921 & 1.014 & 1.023 \\
0.86 & RMS & 4.439 & 4.508 & 4.508 \\
& NRMS & 0.931 & 1.014 & 1.023 \\
\hline
\end{tabular}

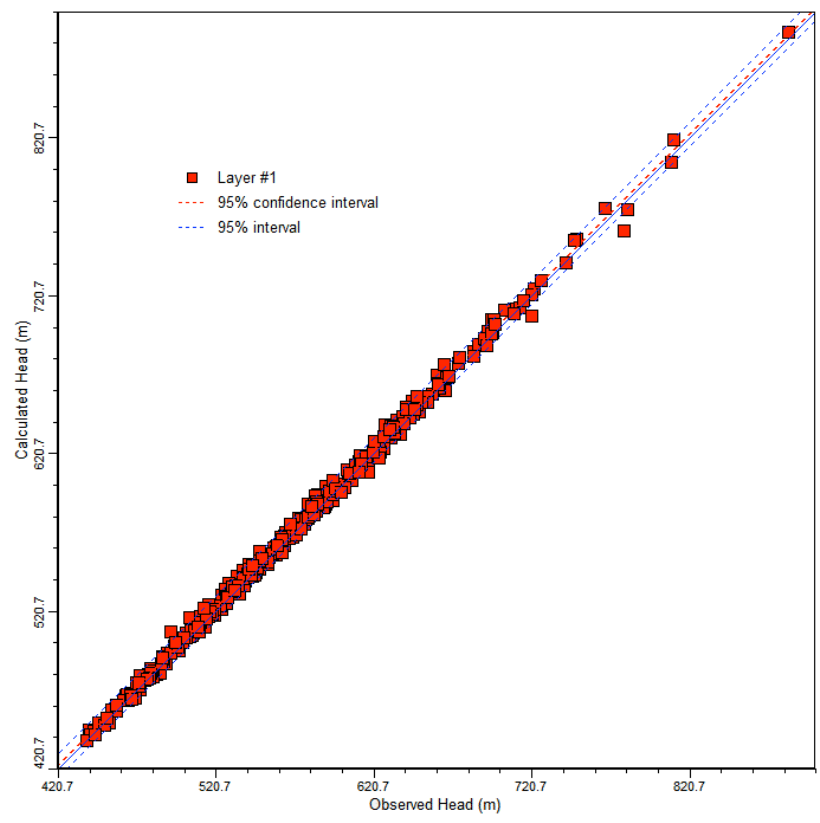

Fig. 4. Observed versus computed heads in flow model during the calibration.

climate modelling studies suggest that precipitation may increase or decrease by as much as $15 \%$ under the scenario of a doubling of atmospheric $\mathrm{CO}_{2}$, depending on latitude and other factors (Government of India, 2008). Examination of historical trends suggests little change in rainfall at the national level, but evidence suggests a mixture of both increases and decreases in rainfall at specific locations (Mall et al., 2006). Many parts of peninsular India, especially the Western Ghats, are likely to experience a $5 \%$ to $10 \%$ increase in total precipitation (Shah, 2009a). Increases in extremely large rainfall events, but a reduction in rainfall days, will exacerbate floods and droughts. According to Rupa Kumar et al. (2006) a $20 \%$, rise in summer monsoon rainfall is forecast across the subcontinent, whereas Gosain et al. (2006) suggest that in the Krishna basin, a $20 \%$ decline in precipitation and corresponding $30-50 \%$ decrease in runoff can be expected.

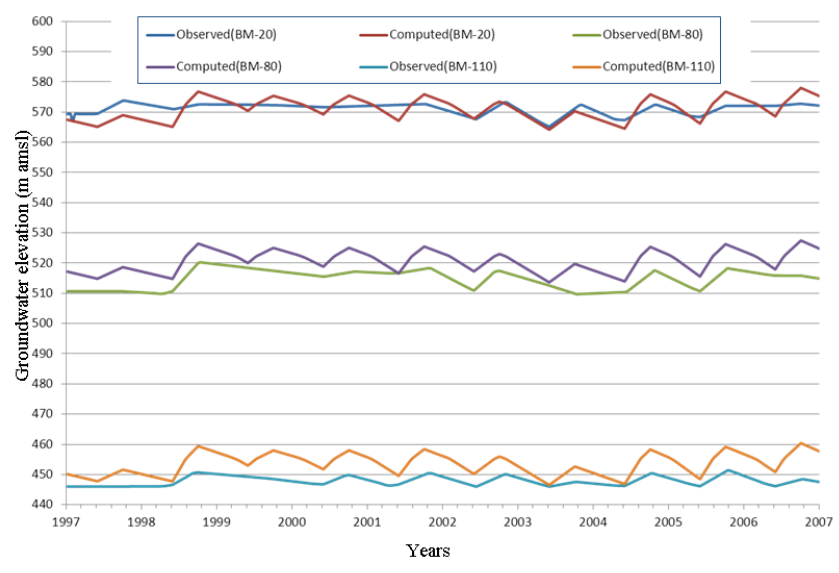

Fig. 5. Observed and simulated water levels during the calibration period for three representative observation wells.

The projected rainfall patterns for the Upper Bhima over the coming decades is not clear. Published regional climate models (RCMS) do not give basin-scale scenarios, and as an alternative to the downscaling of the IPCC RCM data sets the control prediction (no change in rainfall variation, scenario A) simply replicated the historical record (1970 to 2009 ) through to 2040 . A modelled increase in rainfall (scenario B) for this study area, from a gradual increase (relative to scenario A) up to $+10 \%$ by 2040 , and gradual reduction in rainfall to $-10 \%$ by 2040 , (scenario C) offers possible endmember scenarios, as shown in Fig. 6. Although the proportion of rainfall that contributes to recharge could also change, as factors such as rainfall duration and intensity, soil moisture content, temperature and land use respond to climate change (Dragoni and Sukhija, 2008), this was not varied in the model since it was accounted for indirectly, to some degree, by the large rainfall variation between scenarios B and C.

\section{Groundwater recharge and development projections}

Watershed development (WSD) activities have been actively promoted for decades as a means of increasing groundwater (and soil-water) availability and thereby boosting crop productivity and rural livelihoods (Calder et al., 2008). Major WSD programs are undertaken to counter groundwater over-exploitation (as well as soil erosion) across the drier rainfed areas of India, including within the Upper Bhima (Garg et al., 2011b). Modelling the anticipated expansion in WSD first requires an estimate of the sub-basin's excess surface water that is available for harvesting. The available discharge for the sub-basin (pre-WSD) as a function of rainfall was calculated from available river flow data recorded at the most downstream gauging stations of the Upper Bhima sub-Basin (Takli and Wadakbal stations) between 1970 and 1995 (National Water Development Agency, 2003), plotted against the mean annual rainfall for the sub-basin. There is a 


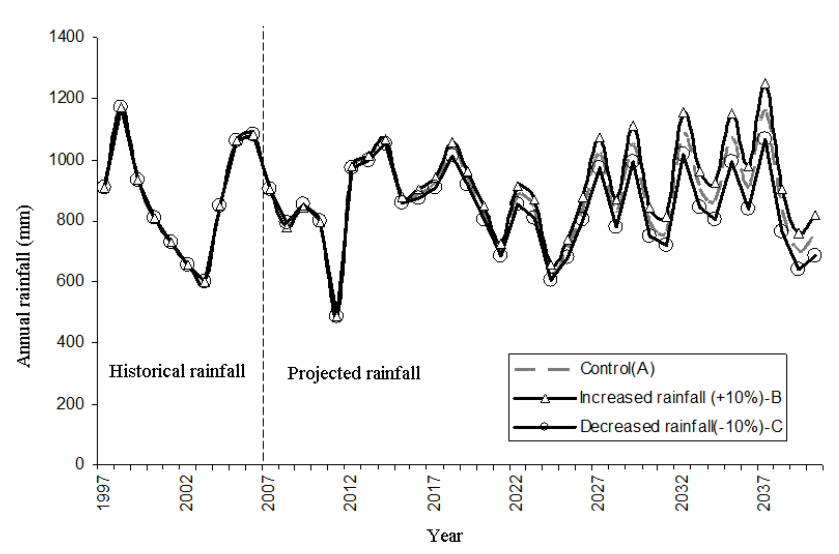

Fig. 6. Historical and projected rainfall sequence used for the predictive scenarios.

reasonable correlation between discharges recorded at these downstream locations and rainfall (Fig. 7). Much of the scatter in the trend is likely to be due to growth in WSD, irrigation canals and the development of large-scale dam projects over this period. The average combined surface water discharges measured at these locations for the period 19701995 is $7258 \mathrm{Mm}^{3} \mathrm{yr}^{-1}$, corresponding to a basin-average rate of $158 \mathrm{~mm} \mathrm{yr}^{-1}$. Whilst it is recognized that much of this water supports agricultural and urban development downstream, it provides an absolute upper limit of the maximum potential resource available for capture using WSD. Projected growth in WSD was assumed to be uniformly distributed across the basin and to steadily increase (linearly) over the prediction period. Peak values of 20 to $30 \%$ of the $7258 \mathrm{Mm}^{3} \mathrm{yr}^{-1}\left(158 \mathrm{~mm} \mathrm{yr}^{-1}\right)$ of surface water potentially available for capture were used in the model. A maximum recharge contribution of $+20 \%$ from WSD was added incrementally to the annual recharge of scenario $C$ (decreasing rainfall) to generate scenario $\mathrm{D}$, and maximum recharge contributions of $+20 \%$ and $+30 \%$ added to scenario B (increasing rainfall) to generate scenarios $\mathrm{E}$ and $\mathrm{F}$ (Table 2). No specific account has been made for changes to evaporative losses from WSD structures as a result of climate change. It is uncertain how this flux may respond differently to changes in temperature, wind patterns or cloud cover so it was not directly included in this assessment.

Four additional pumping regimes were also assessed (scenarios $2-5)$. Two growth rates $(+5 \%$ and $+10 \%)$ and two negative growth rates $(-5 \%$ and $-10 \%)$ were modelled, based against the control rate (scenario 1). These were included to assess changes in groundwater demand. The alphanumeric input matrix of rainfall, WSD and pumping inputs for all $30(6 \times 5)$ scenarios that were modelled is shown in Table 2.

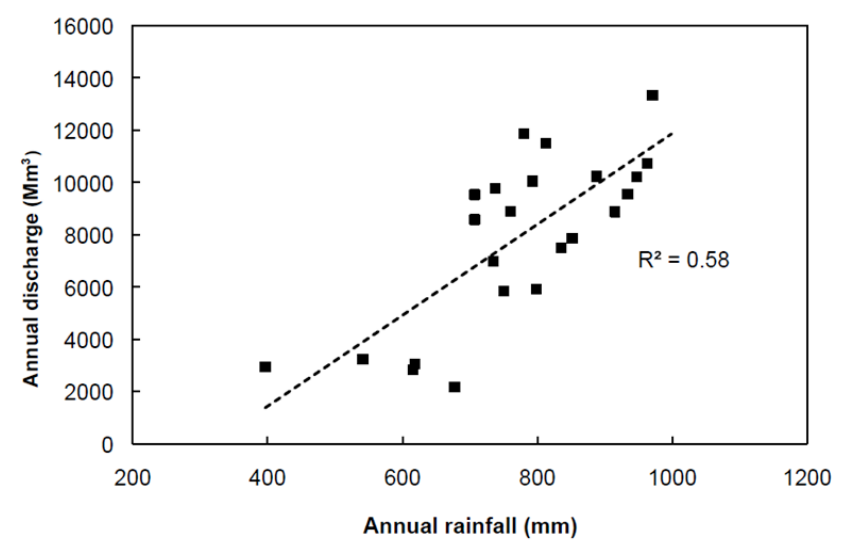

Fig. 7. Annual basin-wise rainfall versus cumulative discharge at Takli and Wadakbal gauging stations, 1970-1995 (Source: NWDA, 2003).

\section{Results}

Basin-aggregated groundwater recharge in the control scenario (A1) varies from $4097 \mathrm{Mm}^{3} \mathrm{yr}^{-1}$ to $3896 \mathrm{Mm}^{3} \mathrm{yr}^{-1}$; groundwater draft varies from $2899 \mathrm{Mm}^{3} \mathrm{yr}^{-1}$ to $3621 \mathrm{Mm}^{3} \mathrm{yr}^{-1}$; and groundwater storage varies from $1199 \mathrm{Mm}^{3} \mathrm{yr}^{-1}$ to $277 \mathrm{Mm}^{3} \mathrm{yr}^{-1}$ between the years 2008 to 2040. Groundwater outflows are only $0.02 \mathrm{Mm}^{3} \mathrm{yr}^{-1}$ in the year 2008 and decline to zero after the year 2030 because of over utilization of groundwater resources. Groundwater outflows are very negligible in all scenarios and decline to zero after the year 2030. In the worst-case scenarios (C3 and D3) groundwater storage varies from 1199 to $681 \mathrm{Mm}^{3} \mathrm{yr}^{-1}$ (C3) and 832 to $735 \mathrm{Mm}^{3} \mathrm{yr}^{-1}$ (D3); recharge varies from 4098 to $3511 \mathrm{Mm}^{3} \mathrm{yr}^{-1}$ (C3) and $4144 \mathrm{Mm}^{3} \mathrm{yr}^{-1}$ to 4945 (D3); and groundwater draft varies from 2899 to $4195 \mathrm{Mm}^{3} \mathrm{yr}^{-1}$ (C3) and 3313 to $4213 \mathrm{Mm}^{3} \mathrm{yr}^{-1}$ (D3). In the best-case scenario (E5) recharge varies from $4144 \mathrm{Mm}^{3} \mathrm{yr}^{-1}$ to $5144 \mathrm{Mm}^{3} \mathrm{yr}^{-1}$; groundwater draft varies from $2899 \mathrm{Mm}^{3} \mathrm{yr}^{-1}$ to $3904 \mathrm{Mm}^{3} \mathrm{yr}^{-1}$; and groundwater storage varies from $1246 \mathrm{Mm}^{3} \mathrm{yr}^{-1}$ to $1242 \mathrm{Mm}^{3} \mathrm{yr}^{-1}$. Groundwater recharge varies from $2899 \mathrm{Mm}^{3} \mathrm{yr}^{-1}$ to $5607 \mathrm{Mm}^{3} \mathrm{yr}^{-1}$ with $30 \%$ WSD (F1) and groundwater storage varies from $1246 \mathrm{Mm}^{3} \mathrm{yr}^{-1}$ to $1977 \mathrm{Mm}^{3} \mathrm{yr}^{-1}$. The number of structures required for artificial groundwater recharge depends on storage capacity and efficiency of the structure. For a typical storage structure dimention of $800 \mathrm{~m} \times 800 \mathrm{~m} \times 0.6 \mathrm{~m}$ which can store $0.38 \mathrm{Mm}^{3}$ of water with $50 \%$ recharge efficiency, 7636 structures are required to recharge $1451 \mathrm{Mm}^{3}$ (20\% development) of additional water. In case of $30 \%$ development, 12726 structures are required to recharge $2148 \mathrm{Mm}^{3}$ of additional water. Whether the combination of different types of structures can be used, viz., checkdams, percolation tanks etc., depends on the hydrogeologic conditions in the area and investment available. The detailed cost and benefit analysis of WSD 
Table 2. Matrix of forecast scenarios covering variations in rainfall (and hence recharge), pumping rates and watershed development (WSD).

\begin{tabular}{lllllll}
\hline & $\begin{array}{l}\text { A } \\
\text { Reproduction } \\
\text { of historical } \\
\text { rainfall }\end{array}$ & $\begin{array}{l}\text { B } \\
\text { Increased } \\
\text { rainfall } \\
\text { to }+10 \%\end{array}$ & $\begin{array}{l}\text { C } \\
\text { Decreased } \\
\text { rainfall to } \\
-10 \%\end{array}$ & $\begin{array}{l}\text { D } \\
\text { (C) }+ \\
\text { WSD to } \\
20 \%\end{array}$ & $\begin{array}{l}\text { E } \\
\text { (B) }+\end{array}$ & $\begin{array}{l}\text { FSD to } \\
\text { (B) }+ \\
\text { WSD to }\end{array}$ \\
\hline 1. Control pumping & A1 & B1 & C1 & D1 & E1 & F1 \\
2.5\% growth in pumping & A2 & B2 & C2 & D2 & E2 & F2 \\
3.10\% growth in pumping & A3 & B3 & C3 & D3 & E3 & F3 \\
4.5\% reduction in pumping & A4 & B4 & C4 & D4 & E4 & F4 \\
$5.10 \%$ reduction in pumping & A5 & B5 & C5 & D5 & E5 & F5 \\
\hline
\end{tabular}

programmes in the Upper Bhima Basin is discussed by Kumar et al. (2012).

Groundwater elevations for three representative observation wells: BM-20 (upper basin), BM80 (middle basin) and BM-110 (lower basin) were selected for presentation of the results for 6 selected scenarios, including the control (A1), best-case (B1), worst-case (C3), and three intermediate-cases (D3, E5 and F1), as shown in Fig. 8. The results for all 30 scenarios are given in Table 3 , expressed in terms of the average groundwater level change measured in all (non-dry) observation wells across the basin for three intervals throughout the simulation period. The major groundwater elevation trends strongly reflect the rainfall conditions associated with each scenario. Relative changes between scenarios tend to be less significant prior to 2020 due to the incremental modelled change in recharge and pumping. The control simulation (A1) suggests that groundwater in the basin is being overexploited, as shown by a long-term steady decline in groundwater elevations even though the control rainfall projection (A) has an overall stable trend (Fig. 8). Under declining precipitation scenarios and highest pumping scenarios (C1-3), groundwater is predicted to fall across the basin by up to $18 \mathrm{~m}$ from the 2007 groundwater levels and by more than $34 \mathrm{~m}$ at some locations along the eastern margins. In this situation groundwater elevations may fall below the critical aquifer depth limit (most permeable weathered portion of the basalt) by approximately 2034. This is also the case under scenario A3, in which the increase in pumping has reduced groundwater levels to $50 \mathrm{~m}$ b.g.l. Under scenario B3, the gradual increase in rainfall only begins to outweigh the over-abstraction caused by current pumping rates by about 2027. Under scenarios A4 and A5, groundwater depletion can be shown to be reversed with a reduction in pumping of $5 \%$ and $10 \%$. Figure 8 also shows that WSD is able to stabilize, and in some cases (such as scenario F1), reverse groundwater declines.

\section{Discussion}

The results from all scenarios without WSD indicate that groundwater elevations may fall by approximately 5 to $6 \mathrm{~m}$ by the year 2020. Given that the majority of pumping takes
Table 3. Average groundwater level change relative to 2007 for all forecast scenarios for three different time periods.

\begin{tabular}{|c|c|c|c|c|c|c|c|}
\hline \multirow[b]{2}{*}{ Scenario } & \multicolumn{3}{|c|}{ Year } & \multirow[b]{2}{*}{ Scenario } & \multicolumn{3}{|c|}{ Year } \\
\hline & 2020 & 2030 & 2040 & & 2020 & 2030 & 2040 \\
\hline A1 & 5 & 9 & 11 & $\mathrm{C} 4$ & 6.1 & 11 & 17.1 \\
\hline A2 & 5.7 & 9.6 & 11.8 & C5 & 5.5 & 10.1 & 15 \\
\hline A3 & 5.8 & 10.4 & 14 & D1 & 5.5 & 8.8 & 10.2 \\
\hline A4 & 5 & 6 & 9 & D2 & 5.5 & 8.1 & 11.3 \\
\hline A5 & 4 & 5.7 & 7.5 & D3 & 5.5 & 8.2 & 11.2 \\
\hline B1 & 5.4 & 8.3 & 7.8 & D4 & 5.1 & 7.8 & 8.9 \\
\hline B2 & 5 & 8.6 & 8.9 & D5 & 4.7 & 6.8 & 7.9 \\
\hline B3 & 5.5 & 9.2 & 9.9 & E1 & 5.1 & 5.4 & 2.8 \\
\hline B4 & 5.2 & 7.1 & 6.3 & $\mathrm{E} 2$ & 5.3 & 6.8 & 3.1 \\
\hline B5 & 4 & 6.1 & 4.7 & E3 & 5.7 & 7.1 & 4.9 \\
\hline $\mathrm{C} 1$ & 6 & 10.8 & 15.8 & $\mathrm{E} 4$ & 4.7 & 6 & 2 \\
\hline $\mathrm{C} 2$ & 6.1 & 11.3 & 16.9 & E5 & 4.3 & 4.1 & 0.8 \\
\hline $\mathrm{C} 3$ & 6.1 & 11.7 & 18.1 & & & & \\
\hline
\end{tabular}

place from dug wells that are less than $20 \mathrm{~m}$ deep and are supplied by the shallow groundwater layers, many would become perennially dry in the coming years. Deepening of wells will not provide a realistic response solution, since well yields decline with depth, and pumping costs will increase greatly. Such a pessimistic forecast would cause much damage to the livelihoods of those dependant on groundwater in the basin. However, the simulations also reveal that the Upper Bhima's groundwater resources can be maintained and possibly enhanced in a sustainable manner for a long time under moderate reductions in pumping rates supplemented by WSD. Under best-case scenarios, of increased rainfall and reduced abstraction and/or modest WSD (scenarios E5, F1 and F5), groundwater can be brought close to the 2007 groundwater elevations and even above.

Despite the assumptions inherent in the modelling of WSD in this study, these results indicate the potential to reverse a projected decline in basin-wide groundwater elevations under the current settings. The challenge is to deliver WSD in a way that is technically and economically effective, whilst taking into account of the water requirements of downstream areas. Garg et al. (2011b) reports that in the Kothapally micro-watershed of the Musi sub-Basin, the surface water outflow was reduced by more than $50 \%$ after the 


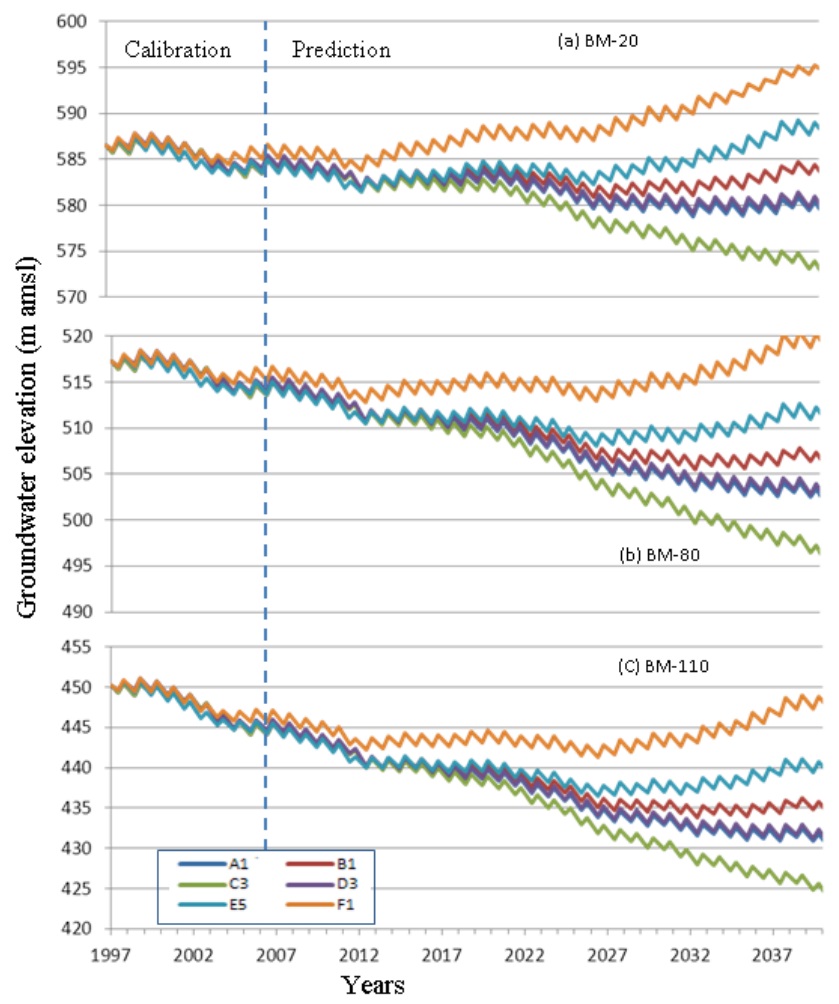

Fig. 8. Observed and simulated water levels for three observation wells between 1997 and 2040 for 6 scenarios (predictions commence in 2008). Note that the curves for scenarios A1 and D3 closely overlap.

implementation of the watershed development programme. When such treatments are applied in a widespread fashion, Garg et al. (2011b) demonstrated that this has significant implications on downstream flows to the Osman Sagar reservoir that provides supply to Hyderabad (the sixth biggest city in India).

Across the Upper Bhima sub-Basin and the Krishna Basin as a whole, more than half of the irrigation water is sourced from groundwater and therefore groundwater-based irrigation practices have a significant bearing on the water resources at the basin scale. Such considerations become even more critical in a case such as the Krishna where most of the available resources within the basin are utilized and there is limited outflow to the sea. This analysis highlights that the detention of up to $30 \%$ of the surface water outflow from this upstream sub-basin comes at a price for the downstream areas that include the Lower Bhima and Lower Krisna subBasins. Major irrigation projects such as the Nagarjuna Sagar reservoir, power generation at Srisailam reservoir and provision of drinking supplies for Hyderabad are key examples of existing water users. A clearer indication of the significance of these flows comes by noting that the harvesting of $2260 \mathrm{Mm}^{3} \mathrm{yr}^{-1}$ (the $30 \%$ excess) is almost 5 -fold greater than the total water demand for Hyderabad of $430 \mathrm{Mm}^{3} \mathrm{yr}^{-1}$
(George et al., 2009). It is fitting to ask if the benefits in sustaining groundwater levels and therefore irrigated areas in the Upper Bhima justify the diminished socio-economic activity in downstream reaches associated with WSD.

Reducing the crop water demand and therefore the magnitude of groundwater pumping is an alternative strategy to keeping groundwater overexploitation in check. Implementation of water saving measures such as micro-irrigation or growing less high-water-use cash crops, such as sugarcane, may offer a plausible alternative, but would need to be undertaken on a sufficiently large scale. Community management of groundwater aimed at creating self-governing groundwater user organizations geared towards sustainable management of groundwater through collective monitoring of groundwater on the one hand, and limiting demand in accordance to groundwater availability on the other, have had widespread success across rainfed areas Andhra Pradesh (World Bank, 2010), and may offer a suitable model for other regions including Upper Bhima.

\section{Conclusions}

The Upper Bhima Basin is a sensitively balanced, finite groundwater resource, and is at risk of being overexploited in the coming decades. A regional groundwater flow model was developed to simulate the groundwater conditions and variability within this basin, based on simplifications and assumptions about hydrological processes and an averaging of parameters such as aquifer thickness, recharge and discharge. The major limitations of such a model are subsurface conceptualization and its distribution of hydrological parameters due to scarce local-level information. The results obtained from the model should be viewed as relative trends of water levels at the basin scale, where local- or microlevel planning requires additional information. The projected annual variation in rainfall pattern that was used for modelling in this study is based on the past rainfall pattern for the region. The actual future rainfall pattern will be influenced in many complex ways by future changes in local climate, and these changes have not yet been confidently predicted or agreed on by climate change modellers for the scale of this study area. Nevertheless, the forecasting applied in this study included a selected range of future changes in rainfall magnitude to model the impact on the region's groundwater, using an adequately calibrated model. As such it was considered to be indicative for trends of the whole-of-basin perspective. The results of the forecast scenarios suggest there to be serious implications for groundwater availability in the basin. Under the control scenario (drawing from historical rainfall patterns with no change in pumping rates or WSD), the results suggest that the depth limit of exploitable groundwater will be reached within the next decade. Stabilization of groundwater levels can be achieved with $20 \%$ of the harvestable surface water flows being recharged to groundwater via WSD 
combined with a $10 \%$ reduction in pumping rates, or by $30 \%$ WSD if pumping remains at current rates.

A challenging dilemma arises in that sustaining the livelihoods of farmers and groundwater baseflow to surface water bodies in the upstream sub-basin through WSD comes at the cost of the downstream users in major irrigation canal project areas, and for urban consumers of water and energy. An answer to this multi-dimensional problem relies upon a hydro-socio-economic trade-off analysis that encompasses both upstream and downstream sub-basins to identify the best solution. Such an analysis should recognize the exchange and inter-dependence between surface and groundwater resources, along with the pre-existing constraints associated with surface water allocation agreements brokered between the three affected riparian states.

Acknowledgements. Financially support for this research was provided by the Australian Centre for International Agricultural Research (ACIAR) administered through the CGIAR Research Program on Climate Change, Agriculture and Food Security (CCAFS). Groundwater Surveys and Development Agency (GSDA) are gratefully acknowledged for making primary and secondary data available for this analysis. We thank Uday Patankar (GSDA), Kaushal Garg (ICRISAT), Biju George (University of Melbourne), Kiran Jella and Venkata Radha (IWMI) for generously sharing their knowledge on related subjects.

Edited by: M. Vanclooster

\section{References}

Allen, D. M., Mackie, D. C., and Wei, M.: Groundwater and climate change: a sensitivity analysis for the Grand Forks aquifer, southern British Columbia, Canada, Hydrogeol. J., 12, 270-290, 2004

Andersen, H. E., Kronvang, B., Larsen, S. E., Hoffmann, C. C., Jensen, T. S., and Rasmussen, E. K.: Climate-change impacts on hydrology and nutrients in a Danish lowland river basin, Sci. Total Environ., 365, 223-237, 2006.

Biggs, T. W., Gaur, A., Scott, C. A., Thenkabail, P., Parthasaradhi, G. R., Gumma, M. K., Acharya, S., and Turral, H.: Closing of the Krishna Basin: Irrigation, streamflow depletion and macroscale hydrology, IWMI Research Report 111, International Water Management Institute, Colombo, Sri Lanka, 44 pp., 2007.

Brouyère, S., Carabin, G., and Dassargues, A.: Climate change impacts on groundwater resources: modeled deficits in a chalky aquifer, Geer basin, Belgium, Hydrogeol. J., 12, 123-134, 2004.

Calder, I. A., Gosain, M. S. R., Rao, M., Batchelor, C., Snehalatha, M., and Bishop, E.: Watershed development in India, Biophysical and societal impacts, Environment, Development and Sustainability, 10, 537-557, 2008.

Chatterjee, R. and Purohit, R. R.: Estimation of replenishable groundwater resources in India and their status of utilization, Curr. Sci., 96, 1581-1591, 2009.

Dragoni, W. and Sukhija, B. S.: Climate change and groundwater: a short review, Geol. Soc. London Sp., 288, 1-12, 2008.
Deolankar, S.: The Deccan Basalts of Maharashtra, India - Their potential as aquifers, Ground Water, 18, 434-437, 1980.

Foster, S., Garduño, H., and Tuinhof, A.: Confronting the Groundwater Management Challenge in the Deccan Traps Country of Maharashtra - India, The World Bank and GW.MATE, Case Profile Collection Number 18, 20 pp., 2007.

Garduño, H. and Foster, S.: Sustainable groundwater irrigation approaches to reconciling demand with resources, World Bank Strategic Overview Series Number 4, 40 pp., 2010.

Garg, K. K., Bharati, L., Gaur, A., George, B., Acharya, S., Jella, K., and Narasimhan, B.: Spatial Mapping of Agricultural Water Productivity using the Swat Model in Upper Bhima Catchment, India, Irrig. Drain., 61, 60-79, doi:10.1002/ird.618, 2011 a.

Garg, K. K., Karlberg, L., Barron, J., Wani, S. P., and Rockstrom, J.: Assessing impacts of agricultural water interventions in the Kothapally watershed, Southern India, Hydrol. Process., 26, 387-404, doi:10.1002/hyp.8138, 2011 b.

Gartley, M. L. , George, B., Davidson, B., Malano, H. M., and Garg, K. K.: Hydro-economic modelling of the Upper Bhima Catchment, India, 18th World IMACS/MODSIM Congress, Cairns, Australia, 13-17, 2009.

George, B. A., Malano, H. M., Khan, A. R., Gaur, A., and Davidson, B.: Urban water supply strategies for Hyderabad, India - Future scenarios, Environ. Model. Assess., 14, 691-704, 2009.

Gosain, A. K., Rao, S., and Basuray, D. :Climate change impact assessment on hydrology of Indian river basins, Curr. Sci., 90, 346-353, 2006.

Government of India (Ministry of Water Resources): Report of the groundwater resource estimation committee, Groundwater Resource Estimation Methodology 1997, Government of India, 113 pp., 1997.

Government of India (Ministry of Water Resources): Preliminary consolidated report on effect of climate change on water resources, Central Water Commission National Institute of Hydrology, 37 pp., 2008.

Immerzeel, W. W., Gaur, A., and Droogers, P.: Remote Sensing and hydrological modelling of the Upper Bhima catchment, IWMI Research paper No. 3, International Water Management Institute, Colombo, Sri Lanka, 2006.

Jyrkama, M. I. and Sykes, J. F.: The impact of climate change on spatially varying groundwater recharge in the grand river watershed (Ontario), J. Hydrol., 338, 237-250, 2007.

Krysanova, V., Hattermann, F., and Habeck, A.: Expected changes in water resources availability and water quality with respect to climate change in the Elbe River basin (Germany), Nord. Hydrol., 36, 321-333, 2005.

Kulkarni, H.: A study of the Deccan basaltic unconfined groundwater system from the Pabal area of Shirur taluka, Pune district, Maharashtra state, PhD Thesis, University of Pune, India, 285 pp., 1987.

Kulkarni, H. and Deolankar, S. B.: Hydrogeological mapping in the Deccan basalts: an appraisal, Journal Geological Society of India, 46, 345-352, 1995.

Kulkarni, H., Deolankar, S. B., Lalwani, A., Joseph, B., and Pawar, S.: Hydrogeological framework for the Deccan basalt groundwater systems, west-central India, Hydrogeol. J., 8, 368-378, 2000.

Kulkarni, H., Uma, B., Phadnis, V., and Robb, R.:Augmenting Groundwater Resources by Artificial Recharge, Detailed case study of Kolwan valley, Mulshi taluka, Pune district, India, 
AGRAR Project Case Study Research Report prepared by the Advanced Centre for Water Resource Development and Management (ACWADAM), Pune, India, 2005.

Kumar, S., Surinaidu, L., Pavelic, P., and Davidson, B.: Integrating cost and benefit considerations with supply- and demand-based strategies for basinscale groundwater management in South-West India, Water Int., 37, 460-477, doi:10.1080/02508060.2012.708601, 2012.

Limaye, S. D.: Groundwater development and management in the Deccan Traps (basalts) of western India, Hydrogeol. J., 18, 543$558,2010$.

Loáiciga, H. A., Maidment, D. R., and Valdes, J. B.: Climate-change impacts in a regional karst aquifer, Texas, USA, J. Hydrol., 227, 173-194, 2000.

Mall, R. K., Gupta, A., Singh, R., Singh, R., and Rathore, L. S.: Water resources and climate change: An Indian perspective, Curr. Sci., 90, 1610-1626, 2006.

Maurya, U. K. and Vittal, K. P. R.: Geological and mineralogical formations on various abiotic edaphic stresses at Malegaon, Baramati, Maharashtra, Clay Research, 30, 61-71, 2011.

McDonald, M. G. and Harbaugh, A. W.: A modular threedimensional finite-difference groundwater flow model, Techniques of Water resources investigation of the United States Geological Survey, USGS, Book 6, Chapter A1, 586 pp., 1988.

National Water Development Agency: Water balance study of the Upper Bhima sub-basin of the Krishna basin, Technical Study No. 77, Government of India, New Delhi, February, 2003.

Phadnis, V., Kulkarni, H., and Uma, B.: Study of Pondhe Watershed Area, Purandar taluka, Pune district, Maharashtra, based on: Rapid Hydrogeological Mapping through Field Studies, prepared by: the Advanced Centre for Water Resource Development and Management (ACWADAM), Pune, India, Technical Report: ACWA/2005/H-1, 2005.

Pavelic, P., Patankar, U., Acharya, S., Jella, K., and Gumma, M. K.: Role of groundwater in buffering irrigation production against climate variability at the basin scale in South-West India, Agr. Water Manage., 103, 78-87, 2012.

Rupa Kumar, K., Sahai, A. K., Krishna Kumar, K., Patwardhan, S. K., Mishra, P. K., Revadekar, J. V., Kamala, K., and Pant, G. B.: High-resolution climate change scenarios for India for the $21 \mathrm{st}$ century, Curr. Sci., 90, 334-345, 2006.
Saha, D. and Agrawal, A. K.: Determination of specific yield using water balance approach - case study of Torla Odha watershed in the Deccan Trap province, Maharashtra state, India, Hydrogeol. J., 14, 625-635, 2006.

Scibek, J. and Allen, D. M.: Modeled impacts of predicted climate change on recharge and groundwater levels, Water Resour. Res, 42, W11405, doi:10.1029/2005WR004742, 2006.

Scibek, J., Allen, D. M., Cannon, A. J., and Whitfield, P. H.: Groundwater-surface water interaction under scenarios of climate change using a high-resolution transient groundwater model, J. Hydrol., 333, 165-181, 2007.

Shah, T.: Taming the Anarchy: Groundwater Governance in South Asia, RFF Press, Washington DC, 310 pp., ISBN 978-1-93311560-3, 2009a.

Shah, T.: Climate change and groundwater: India's opportunities for mitigation and adaptation, Environ. Res. Lett., 4, 035005, doi:10.1088/1748-9326/4/3/035005, 2009b.

Singhal, B. B. S. and Gupta, R. P.: Applied hydrogeology of fractured rocks, Kluwer Academic Publishers, 408 pp., 1999.

Varanou, E., Gkouvatsou, E., Baltas, E., and Mimikou, M.: Quantity and quality integrated catchment modelling under climate change with use of soil and water assessment tool model, J. Hydrol. Eng., 7, 228-244, 2002.

Venot, J. P.: Rural dynamics and new challenges in the Indian water sector: the trajectory of the Krishna Basin, South India, in: River Basin Trajectories: Societies, Environments and Development, edited by: Molle, F. and Wester, P., CAB International 2009, 214 237, 2009.

Waterloo Hydrologic: Visual MODFLOW Version 4.3 User manual, Waterloo Hydrologic Inc. Waterloo, Ontario, Canada, 2002.

World Bank: Deep wells and prudence: Towards pragmatic action for addressing groundwater overexploitation in India, Report 51676, The International Bank for Reconstruction and Development/The World Bank 1818 H Street, NW, Washington DC, 20433, USA, 100 pp., 2010. 